Original Article

\title{
The Challenges in Implementation of Halal Vaccine Certification in Malaysia
}

\author{
Johari Ab Latiff ${ }^{\left.1^{*}\right)}$, Zalina Zakaria ${ }^{2)}$ and Sa'adan Man ${ }^{3)}$ \\ ${ }^{1}$ Department of Shariah and Law, Academy of Islamic Studies, University of Malaya, 50603 Kuala Lumpur \\ 2 Department of Shariah and Law, Academy of Islamic Studies, University of Malaya, 50603 Kuala Lumpur \\ 3 Department of Figh and Usul, Academy of Islamic Studies, University of Malaya, 50603 Kuala Lumpur \\ *Corresponding author: Johari Ab Latiff I Email: johariablatiff81@gmail.com
}

Received: 14 November 2020; Revised: 22 January 2021; Accepted: 07 February 2021; Published: 20 March 2021

\begin{abstract}
The global halal pharmaceutical sector is valued at USD 132 billion by 2021. This sector is seen as a high priority development area. Apart from food products, Muslim consumers are also becoming more aware of halal pharmaceuticals. They are beginning to see the potential detrimental effects created by product development, testing, and production, all of which could be deviating from the halal values. Based on this uncertainty, the public at large is increasingly questioning the sources of their pharmaceutical products. Under such circumstances, the situation of children contracting contagious diseases has been noted to be on the rise in Malaysia, especially in the last few years. As a result, health authorities are concerned that there would be parents who may reject the immunization programs for their children out of the fear that the vaccines used may infringe on some strict religious rules. A conservative Muslim may sometimes reject the inoculation over concerns that some vaccines were derived from contents of pigs or porcine, of which Muslims are forbidden to consume. Vaccines are part of the pharmaceutical products, and like all other pharmaceutical products, they can be developed using halal ingredients, which can replace the use of non halal contents or animal products and their derivatives for medication. The implementation of halal certification for vaccines is strictly bounded by Shariah law and Fatwa. Malaysia. As a Muslim country, Malaysia is widely and globally regarded as one of the pioneers in halal pharmaceuticals. This can be traced to its world first halal pharmaceutical standard which was introduced as MS 2424: Halal Pharmaceuticals - General Guidelines since 2012, with first revision in 2019. Nonetheless, from then until presently, Malaysia has not been able to provide halal certification for the vaccine products. The implementation of the halal certification for vaccine products in Malaysia may have been triggered by the use of non-halal or forbidden ingredients in the manufacturing of those vaccine products. Thus far, the Malaysian Standard of the MS 2424 is the only standard, and it is also only a general guide. There is a need to develop a more thorough manual that can be adhered to by pharmaceuticals. This necessity to certify vaccine products as halal for the context of Malaysia has thus put the Halal Certification Body, like JAKIM, to be in limbo.
\end{abstract}

Keywords: Vaccine, Halal Certification, Malaysian Standard MS 2424

\section{INTRODUCTION}

Various forms of diseases that plague our society today are caused by microorganisms, such as bacteria, viruses, fungus and many more. Some of these diseases can be prevented by using early preventive treatment methods with vaccines. Such diseases are also known as vaccine-preventive diseases, among which are small pox, measles, pertussis, poliomyelitis, haemophiles influenza, 
tuberculosis, and others (Azizi Ayob, 2017). Vaccines were discovered over 300 years ago to prevent the spread of infectious diseases, and vaccines can also save lives. However, vaccines in the early stages of their discovery were limited to a few diseases, and their effectiveness had also been limited. In general, using vaccines to treat diseases as a method, can be very effective if the vaccines were used among a group of people who have been exposed to the disease before. These people are then given full vaccine treatment according to the required dose at a given time. If only a handful of individuals had taken the vaccine in an area or community, then the group immunity (herd immunity) is not achievable. Group immunity is very important because access and control of the disease is very closely related to the population that has immunity to the disease. At the same time, the identified vaccines can be given to the community that has not been infected. Thus, vaccines play a role in preventing harm, in the event of disease transmission (Azizi Ayob, 2017). The concept of halal vaccines has been floating around for a few years now, but thus far, nothing concrete had emerged in support of the issue. There is, at present, limited knowledge and little relevant empirical data to suggest the possibility of producing halal vaccines globally. In Malaysia, a medicinal product that is intended for halal certification must first obtain approval from the Drug Control Authority (DCA) to market. The DCA will then mark that the product had been reviewed for safety, quality and efficacy, according to the Drug Registration Guidance Document (DRGD), under Regulation 29, Control of Drugs and Cosmetics Regulations 1984 (Khoo et al., 2020), before the product can apply for halal certification.

A vaccine contains an active component or the antigen. It is an immunogen, the administration of which, is intended to stimulate the immune system so as to result in the prevention, amelioration, or therapy of any disease or infection. Vaccines for human use which are registered with the Drug Control Authority (DCA), Ministry of Health Malaysia (MOH) include one or more of the following (Department of Standard Malaysia, 2019):

a) Microorganisms inactivated by chemical/physical means that retain appropriate immunogenic properties;

b) Living microorganisms that have been selected for their attenuation whilst retaining immunogenic properties;

c) Antigen extracted from microorganisms, secreted by them or produced by recombinant DNA technology; or

d) Antigens produced by chemical synthesis in vitro.

The antigens maybe in their native state, truncated or modified, following introduction or mutations, detoxification by chemical or physical means, and/or aggregated, polymerized or conjugated, to a carrier to increase immunogenicity. Antigens may be presented plain or in conjunction with an adjuvant, or in combination with other antigens, additives, and other excipients (Department of Standard Malaysia, 2019).

Vaccines are basically in the pharmaceutical group; they may include biopharmaceuticals (vaccines, recombinant products, monoclonal antibody products, gene therapy products etc.), radiopharmaceuticals, health supplements, traditional medicines, and investigational medicinal 
products. In terms of halal definition, pharmaceuticals products that contain ingredients permitted under the Shariah law and Fatwa need to abide by the following requirements (Department of Standard Malaysia, 2019):

a) Do not contain any parts or products of animals that are non-halal or any parts or products of animals which are not slaughtered according to Shariah law and Fatwa;

b) Do not contain najs according to Shariah law and Fatwa;

c) Safe and efficacious for human use according to prescribed dosage, of quality and hygiene;

d) Not prepared, processed or manufactured using equipment contaminated with najs according to Shariah law and Fatwa;

e) Do not contain any human parts or its derivatives that are not permitted by Shariah law and Fatwa;

f) During the preparation, processing, handling, packaging, storage and distribution, the halal pharmaceutical products are physically segregated from any other pharmaceutical products that do not meet the requirements stated in items a), b), c), d), e) or any other items that have been decreed as non-halal and najs by Shariah law and Fatwa.

Shariah law in Malaysia is the laws of Islam according to the Mazhab of Shafie or the laws of Islam in any of the other Mazhabs of Hanafi, Maliki and Hanbali, which have been approved by the Yang di-Pertuan Agong to be in force in the Federal Territory, or the Ruler of any State to be in force in that state within Malaysia (Department of Standard Malaysia, 2019, and the Administration of Islamic Law Federal Territories Act, 1993).

Fatwa means any religious decree which is verified by an authority related to the religion of Islam, and is approved by the Yang di-Pertuan Agong to be in force in the Federal Territory, or by the Ruler of any State to be in force in that state within Malaysia (Department of Standard Malaysia, 2019, and the Administration of Islamic Law Federal Territories Act, 1993).

\section{MATERIALS AND METHODS}

\subsection{Materials}

The reference materials are the Holy al-Quran, books, articles journal, conference papers, standards, legal statutes, guidelines and relevant websites that are considered relevant to this study. It is intended to ensure that the references referred to a reliable and accurate.

\subsection{Methods}

In general, qualitative methods are used in this study. Qualitative method is one of the techniques in conventional research. This qualitative research is narrative and verbatim descriptive written. Qualitative research using various philosophies-equation, investigation strategy, data collection methods, analysis and interpretation (Creswell et al., 2009). Qualitative research also refers to the meaning, concept, definition, character, metaphor, symbol and subject matter (Berg et al., 2009). A research method obtained through the searching of the literature through in documents and several electronic databases. A literature search in the data base using the keyword "Vaccine, Halal Certification and Malaysian Standard MS 2424". 


\section{RESULTS AND DISCUSSION}

\subsection{Non-Halal Material}

A vaccine product is derived from the combination of active and excipient ingredients. These substances can be obtained from a variety of sources like animal, plants, and synthetic origin. The animal sources may be porcine, or its derivatives, dead animals, or blood (Khoo et al., 2020). All these are haram or forbidden for Muslims to consume. However, the materials are usually used as the basis in producing vaccines. The difficulty of the industry in obtaining halal ingredients could cause vaccine products to be in a state of dilemma because it is difficult to be certified as halal, as what is currently happening in Malaysia. In Islam, Muslims are required to follow the divine law, which is authoritative. The Holy al-Quran says:

"Therefore, (O Believers) eat of the lawful and good things that Allah has provided for you, and be grateful for His favours, if it is true that you only worship Him. Indeed, Allah has forbidden you that which dies of itself, blood, and the flesh of swine; also, any flesh consecrated to something other than in the name of Allah. But whoever is compelled by necessity (to eat any of this) not intending to sin or transgress (regarding the quantity eaten), will find Allah Most Forgiving, Most Merciful". (Q.S. An-Nahl 16:114-115).

The excerpt above is the evidence explaining why the Muslims abstain from using haram material, or consuming porcine or its derivatives. To sum up, the first challenge in implementing halal certification for vaccines is due to the non-halal raw materials used. The current Fatwa in Malaysia seems to hold the view that vaccines produced from sources of porcine origin are not permissible. Alternatively, porcine derivative-free vaccines are prioritized for use unless there is an urgent need to use such products.

\subsection{Malaysian Standard MS 2424: 2019 is only a General Guide}

The Malaysian Standard (MS) is a document developed by the consensus and approval of a recognized body. It contains rules, guidelines, or characteristics for products or methods of processing which are related. It includes the terms of administration in which compliance is not mandatory (Standards of Malaysia Act 1996 (Act 549). The Malaysian Standard MS 2424 serves as a general guideline denoting the production, handling, and storage of halal products, as has been gazetted by the Government of Malaysia. This is also inclusive of vaccine products. The issue of halal certification is central to the global acceptance of halal products. However, at present, the Malaysian halal certification body, JAKIM, does not carry a specific standard operating procedure (SOP) that can provide the halal certification of vaccine products (Johari Ab Latiff, 2018). The process to provide halal certification for vaccines or vaccine products appear to be much more complex than it is for food, cosmetics, and logistics.

Based on the MS 2424 standard, it can be identified that the content of the standard is just a mere guideline. Therefore, the standard would require a more comprehensive interpretation and implementation. Overall, the halal certification body needs to develop a specific halal certification procedure or manual for the certification of halal vaccines and product certifications. This includes the determination of relevant Fatwa as is the case of vaccines that have gone through the additional process of removing the porcine-derived ingredients, or where the impure substance has been completely transformed and changed into a new substance, different from its origin. A thorough 
discussion between scholars from both the religious and scientific institutions may be necessary so as to determine its permissible or forbidden status.

\subsection{The Readiness of the Halal Certification Body}

Another challenge in implementing the halal certification to vaccines is the readiness of the halal certification body. Although JAKIM has long been implementing halal certifications, the process for vaccines has not been smooth because the halal certification for vaccine products requires more in-depth knowledge, in particular, the vaccine products. This means that a more sophisticated technical expertise is required (Johari Ab Latiff, 2018). In addition, Malaysia is still in the midst of setting up a factory that produces halal vaccine products, and this would involve the need to obtain more information before the halal certification bodies are able to process the implementation. In this regard, JAKIM has to ensure that there are sufficient and qualified personnel available, and that training is provided. Overall, to ensure the readiness of JAKIM in producing halal certifications, it needs to work with other agencies and industries, particularly the National Pharmaceutical Regulatory Agency (NPRA), and the Ministry of Health Malaysia so as to be able to implement the halal certification for vaccine products.

\subsection{The Readiness of the Industries}

One of the important factors for implementing the halal certification of vaccine products is the readiness of manufacturers or industries. The pharmaceutical industry must prepare the technical details and considerations when implementing the use of halal vaccines, following the pharmaceutical standards of Good Manufacturing Practices (GMPs) (Peng et al., 2013). Following this, factory facilities must be dedicated to the halal concept so as to ensure that the ingredients used are halal. Moreover, the pharmaceutical industry must also comply with all the standards and requirements established by the halal certification bodies and respective authorities (Johari Ab Latiff, 2018). In fact, it is very difficult for the vaccine manufacturers or the pharmaceutical industry to make any changes, no matter how small, as stated in the context, because the process involves time and cost.

\section{CONCLUSION}

As has been noted, for the purpose of implementing halal certifications for vaccine products in the context of Malaysia, as a Muslim country, some obstacles and challenges need to be resolved, either by JAKIM, other halal certification bodies and agencies, or even the pharmaceutical industry itself. The production of vaccines or vaccine products must be obtained from halal sources, either from plants or animals' origin. The halal certification body, JAKIM, needs to explain how the process is conducted by developing a thorough manual that shows the procedure for the halal certification to be approved, specific to those vaccine products. The implementation of the halal certification of vaccine products is complex. More in-depth knowledge about the products and their ingredients and sources need to be examined. The process also requires technical expertise which encompass qualified and trained personnel and know-hows. The readiness of the pharmaceutical industry in changing any of the vaccine contents, providing a halal system of the process and halal facilities may take time even though the halal certification is an important step towards making vaccine products safe for Muslims, in general. 
Acknowledgments: The authors extend appreciation to The Department of Islamic Development Malaysia (JAKIM) and Public Service Department Malaysia (JPA) for their sponsorship and support.

Conflicts of interest: No conflict of interest associated with this work.

\section{References}

1. Administration of Islamic Law Federal Territories Act 1993 (Act 505).

2. Azizi Ayob, Vaksin, Antara Babi, Yahudi dan Konspirasi, (Selangor: PTS Publishing House Sdn. Bhd, 2017).

3. Berg, Bruce Lawrence, Qualitative Research Methods for Social Science, Seventh Edition (Boston: Allyn \& Bacon, 2009).

4. Creswell, John W., and J. David Creswell. Research design: Qualitative, quantitative, and mixed methods approaches. Sage publications, 2009).

5. Department of Standards Malaysia, MS 2424:2019 Halal Pharmaceuticals General Guidelines (First Revision), (Selangor: Department of Standards Malaysia, 2019).

6. Johari Ab Latiff. (2018). Updates on new and emerging halal standards (Paper Work). $2^{\text {nd }}$ International Halal Technical Capacity Development Programme (IHTCDP) 2018. Jabatan Kemajuan Islam Malaysia (JAKIM) and Dagang Halal. Le Méridien Hotel Putrajaya.

7. Khoo, Yvonne SK, A. Ab Ghani, A. A. Navamukundan, R. Jahis, and A. Gamil. "Unique product quality considerations in vaccine development, registration and new program implementation in Malaysia." Human vaccines \& immunotherapeutics 16, no. 3 (2020): 530-538.

8. Peng, Kenny, and R. H. Abdul Karim. "Good Manufacturing practices for halal pharmaceuticals." Phamaceutical engineering 33, no. 4 (2013): 493-501.

9. Pharmaceuticals: "The pharmaceutical industry has been steadily growing over the last decade"(2020, November , 1), Retrieved from https://www.mida.gov.my/home/pharmaceuticals/posts/

10. Standards of Malaysia Act 1996 (Act 549)

(C) 2021 by the authors. Submitted for possible open access publication under the terms and conditions of the Creative Commons Attribution (CC BY) license (http://creativecommons.org/licenses/by/4.0/). 